\title{
The Analysis of Government Expenditures in the European Union
}

\section{Analiza wydatków rządowych w krajach Unii Europejskiej}

\section{Florica Mioara Serban*, Carmen- Elena Stoenoiu, Ciprian Cristea}

\author{
Technical University of Cluj-Napoca, Department of Electrical Machines and Drives, \\ Romania \\ E-mails:*Florica.Serban@emd.utcluj.ro,Carmen.Stoenoiu@emd.utcluj.ro, \\ Ciprian.Cristea@emd.utcluj.ro
}

\begin{abstract}
This article analyses data on general government expenditure, at the level of the European Union (EU 28) according to the Classification of the Functions of Government - COFOG over the 2008-2017 period. Data shows that the expenditures increased at the beginning of the economic crisis in all EU countries, being followed by a slowdown in expenditures growth. All countries have adopted policies in order to reduce government expenditures towards the end of the period, aiming to increase their efficiency. Usually in high-income countries, compared with low-income countries, government expenditures are much larger as percent of gross domestic product (GDP), but the relations are not very strong though.
\end{abstract}

Key words: government expenditure, COFOG, Gross Domestic Product (GDP), EU 28

\section{Streszczenie}

W tym artykule przeanalizowano dane dotyczące wydatków instytucji rządowych i samorządowych na poziomie Unii Europejskiej (UE 28) zgodnie z klasyfikacją funkcji rządu - COFOG w latach 2008-2017. Dane pokazują, że wydatki wzrosły na początku kryzysu gospodarczego we wszystkich krajach UE, po czym nastąpiło spowolnienie ich wzrostu. Wszystkie kraje przyjęły polityki mające na celu zmniejszenie wydatków rządowych pod koniec tego okresu, mając na celu zwiększenie ich trafności. Zwykle w krajach o wysokich dochodach, w porównaniu z krajami o niskich dochodach, wydatki rządowe są znacznie większe niż procent produktu krajowego brutto (PKB), ale powiązanie to nie jest jednak bardzo silne.

Slowa kluczowe: wydatki rządowe, COFOG, Produkt Krajowy Brutto (PKB), EU 28

\section{Introduction}

Nowadays the Government's role in public society has increased, requiring the allocation of more public funds, in order to provide free and quality public services and goods to citizens. Government expenditures are very diverse, including sectors such as country's defence services, public order and national security, education and public health, environmental protection, social security, public administration and economic affairs. The issue of government expenditures has been studied in various papers - further on is presented a brief description of the subject discussed by authors worldwide.
The impact of government expenditures on education as GDP per capita of Tunisia and Morocco was analyzed in (IFA, GUETAT, 2018,), concluding that public expenditure on education serves to increase the GDP per capita of the two countries. Soft computing approach was applied in (Maksimović, Jović, Jovanović, Anicić, 2017) to predict the gross domestic product (GDP) according to several factors of health care expenditure.

Electoral impacts on the allocation of public expenditures was studied by (Vergne, 2009), the author concluded that for the election-year, public spending 
shifts towards more visible current expenditures, in particular wages and subsidies, and away from capital expenditures.

In (Castro, Martins, 2018) the authors have investigated the political opportunism at aggregated and disaggregated levels of public expenditures and concluded that the expenditure components that have proved to be more related to that behaviour are public services, education, social protection and some sub-components of health expenditure, items that tend to generate outcomes that are more visible to voters. The influence of healthcare expenditure on the economic growth was analyzed in (Mladenovic et al., 2016) using adaptive neuro-fuzzy technique in order to detect the predominant factors affecting the forecasting of economic growth. In (Gamlath, Lahiri, 2018) the authors developed an overlapping generations model to examine how public and private education expenditures impacts on economy's long run outcomes. The level of public expenditure for education and healthcare in EU countries, as well as the relations between them, considered as input, and several social indicators, as output, were analyzed in (Mărginean, 2014). The comparison shows that the most developed countries allocate the largest resources for these areas and have the best performance, but the relations are not very strong though. In literature, several authors try to delimit public spending according to their effect, dividing them into productive and non-productive costs (Aschauer, 1989; Barro, 1990, 1991), saying that only the productive ones contribute to economic growth. Thus, (Kormendi, Meguire, 1985; Schultz, 1961) considers that defence and education expenditure is unproductive, while (Barro, 1991) falls into the category of productive arguing that public education is an investment in human capital with long-term effect. The theory of human capital is discussed by (Schultz, 1961; Becker, 1962), focusing on investing in education and training and (Lucas, 1988) develops the idea of investing in education, in its endogenous growth model.

The purpose of this article is to examine government expenditures in European Union countries in order to identify their tendency both in structure and dimension, knowing that all countries are constantly striving to build policies that will allow them to increase efficiency.

\section{Government expenditures - structure and evo- lution}

This study is based on statistical data regarding government expenditure (as \% of GDP) obtained from Eurostat database (Annual government finance statistics). In the analysis were comprised 28 EU countries (Belgium - BE, Bulgaria - BG, Czech Republic - CZ, Denmark - DK, Germany - DE, Estonia - EE, Ireland - IE, Greece - EL, Spain - ES, France - FR, Croatia - HR, Italy - IT, Cyprus - CY, Latvia - LV,
Lithuania - LT, Luxembourg - LU, Hungary - HU, Malta - MT, Netherlands - NL, Austria - AT, Poland - PL, Portugal - PT, Romania - RO, Slovenia - SI, Slovakia - SK, Finland - FI, Sweden - SE, United Kingdom - UK). More specifically, this paper focuses and examines government expenditures by functional classification over 2008-2017 periods (2017 being the latest year with available data for most countries). According to this classification, expenditures are delimited taking into account the functions of the government. This classification can be found on the European Union website under the name of COFOG (The Classification of the Functions of Government). According to this classification, government expenditures are divided into ten major categories of expenditure: general public services, defence, public order and safety, economic affairs, environmental protection, housing and community affairs, health, recreation, culture and religion, education, social protection. These expenditures are further split into other categories that are presented further on.

The slowdown in economic growth that has occurred in all EU countries since 2008 has had an impact on real GDP. It also had a strong negative effect on the labour market and, implicitly, on public revenues, which, in each country, led to increasing pressures on the way public expenditure was allocated.

Figure 1 shows Government expenditures as \% of GDP between 2008-2017 for EU countries.

The highest level of government expenditures has been recorded in countries like France, Belgium and the Nordic countries (Denmark, Finland). In these countries the government expenditures were above the EU average (Figure 1) with values between 50$60 \%$ of GDP. The lowest values of government expenditures were found in the last countries that joined the EU such as Romania and Bulgaria, as well as the Baltic countries Estonia, Latvia, Lithuania, where total government expenditures were below $40 \%$ of GDP. The highest fluctuations occurred in Ireland, country having the highest expenditures (65\% of GDP in 2010) among all EU countries over the analyzed period. After 2010 in Ireland, government expenditures have been on a declining trend, in 2017 recording the lowest value in the EU, only $26.3 \%$. High fluctuations also occurred in Greece (62.3\% in 2013 and $47.3 \%$ in 2017) and Slovenia (59.5\% in 2013 and $43.2 \%$ in 2017). In the other EU countries, government expenditures have fallen in the values of $40-50 \%$.

Figure 2 presents government expenditures by type, knowing that each state authority tends to carry out public expenditure according to its specific functions. The classification of Government functions done by COFOG (useful international standard, established by O.N.U.), has allowed the analysis of resource allocation between sectors and the answer to the question: Where were public money spent? for each of the surveyed countries, in 2017. 


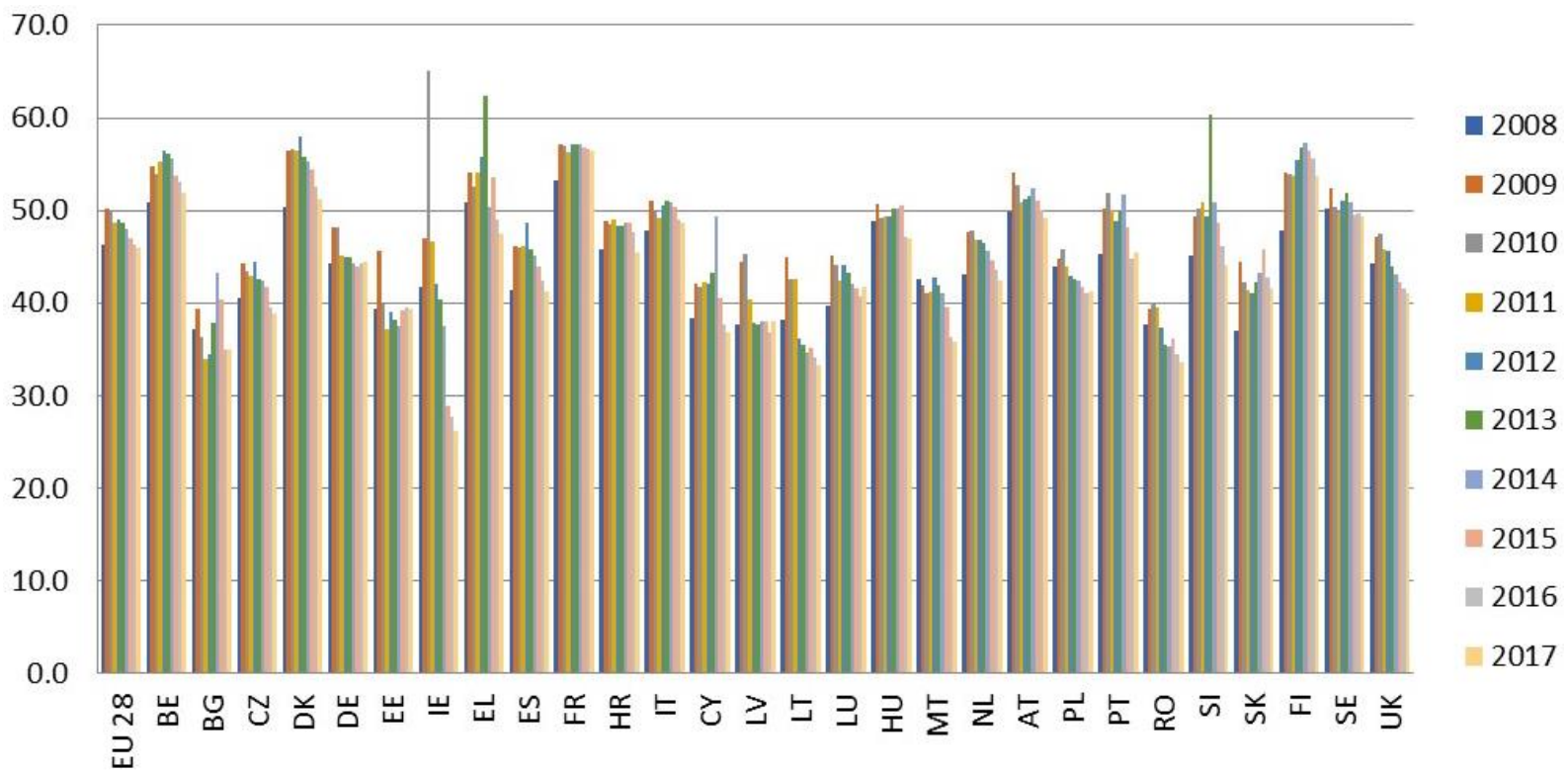

Figure 1. The evolution of government expenditure as \% of GDP over 2008-2017 period, source: processed by authors based on data from Eurostat (gov_10a_exp)

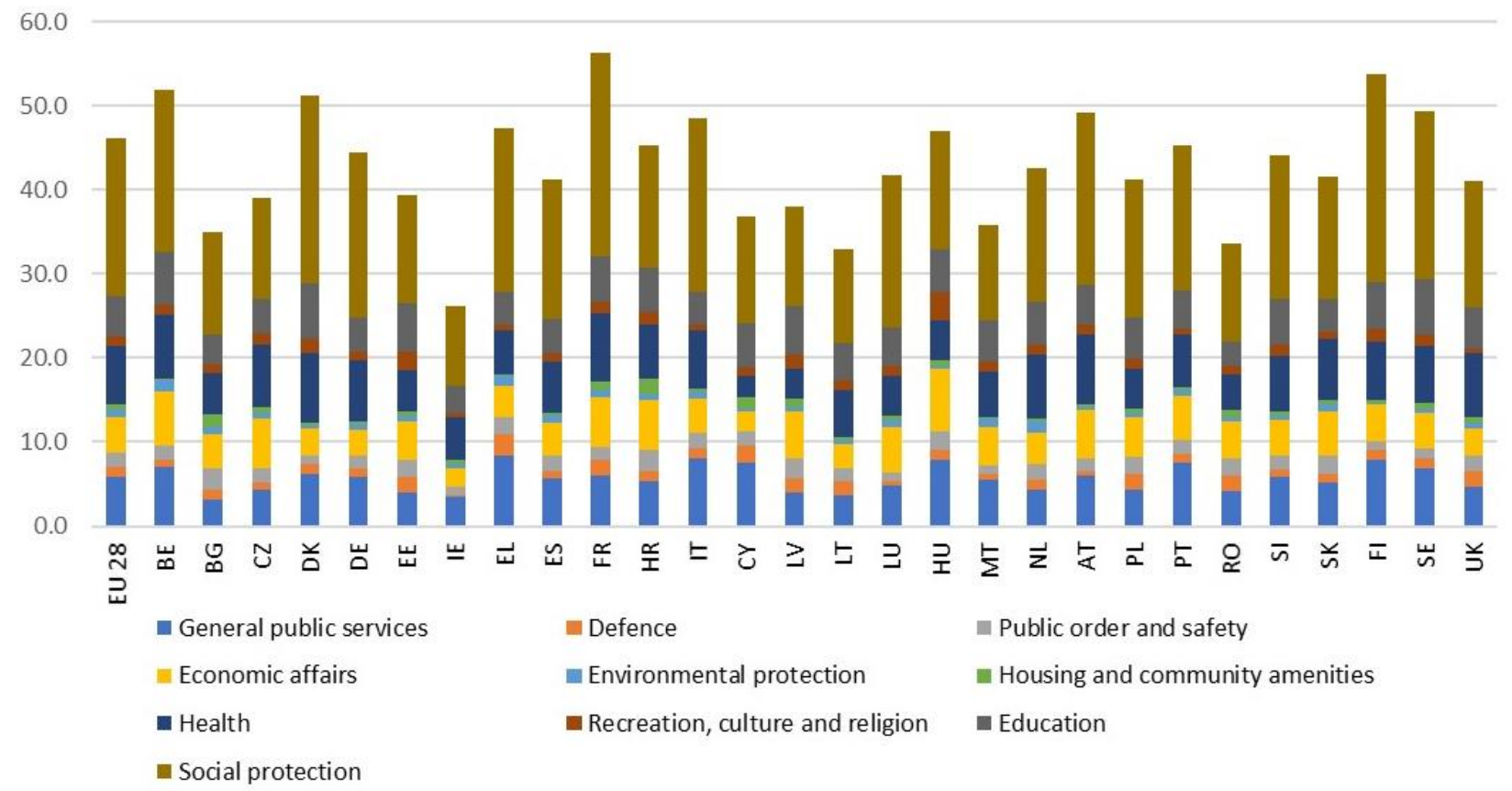

Figure 2. General Government expenditure by function in 2017, source: processed by authors based on data from Eurostat (gov_10a_exp)

Between 2008 and 2017 period the highest government expenditures were recorded for the indicator of social protection in all countries. The share of social protection expenditure in the total expenditures at EU 28 level increased from $38.2 \%$ to $41.1 \%$. The highest values were recorded in Denmark $(24.8 \%$ of GDP in 2010) and the lowest values in Ireland (9.5\% of GDP in 2017), low values were also registered in Romania, Bulgaria and the Baltic countries. In 2017, in the EU-28 countries more than half of the government expenditures were devoted to 'social protection'
(41.1\% of total expenditure or $18.8 \%$ of GDP) followed by 'health' (15.3\% of total expenditure or $7 \%$ of GDP), 'general public services' (12.8\% of total expenditure or $5.8 \%$ of GDP), 'education' (10.2\% of total expenditure or $4.6 \%$ of GDP) and 'economic affairs' (8.9\% of total expenditure or $4.0 \%$ of GDP), 'public order and safety' (1.7\% of GDP), 'defence' (1.3\% of GDP), 'recreation, culture and religion' ( $1.1 \%$ of GDP), 'environmental protection' $(0.8 \%$ of GDP) and 'housing and community amenities' (0.6\% of GDP). 


\subsection{General public services}

According to COFOG, government expenditure on general public services at European Union level are divided in: executive and legislative organs; financial and fiscal affairs, external affairs; foreign economic aid; general services; basic research; research and development (R\&D) on general public services; general public services not elsewhere classified (n.e.c.); public debt transactions; transfers of a general character between different levels of government.

At the level of the EU 28, expenditures on general public services recorded a lower level in 2017 (5.8\% of GDP) compared to 2008 (6.5\% of GDP). During this period, there was an ascending trend until 2013 (6.9\% of GDP), followed by a decreasing one. Throughout the examined period, Greece recorded the highest spending on General public services, reaching a maximum of $12.9 \%$ of GDP in 2011; large expenditures were also recorded in Hungary $10.1 \%$ of GDP in 2013, Cyprus $9.5 \%$ of GDP in 2012, Italy $9.4 \%$ of GDP in 2012 and Portugal 9.3\% of GDP in 2013.

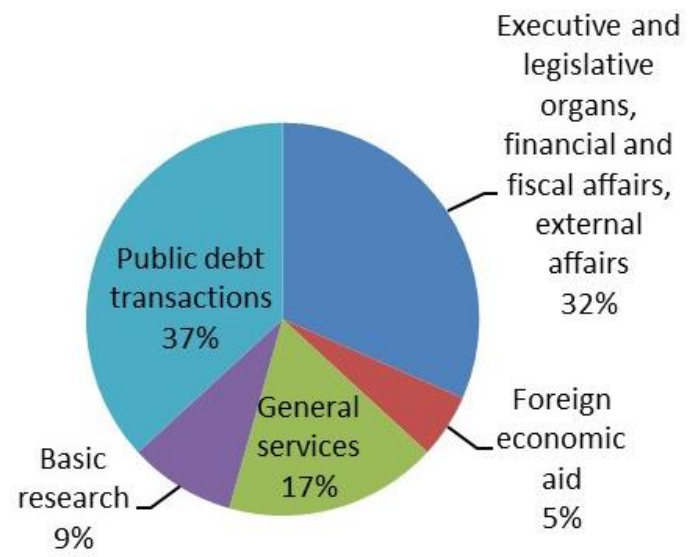

Figure 3. The structure of expenditures on general public services in 2017 at the EU level, source: processed by authors based on data from Eurostat (gov_10a_exp)

Figure 3 shows the structure of expenditures on general public services in 2017. It can be noticed that most important parts are allocated for public debt transactions (37\%), being followed by the executive legislative organs, financial and fiscal affairs, external affairs (32\%). The lowest expenditures were registered in Bulgaria, 2.8\% of GDP, in 2016, respectively $3.2 \%$ of GDP in 2017, Estonia $3.2 \%$ of GDP in 2008 and Ireland 3.4\% of GDP in 2017. Among these expenditures, according to figure 3 , public debt transactions (interest, payable on general government debt instruments) represent the largest share of expenditure at EU level (37\% of general public services in 2017), followed by executive and legislative organs, financial and fiscal affairs, external affairs (employees' wages) which amounted $32 \%$ of general public services in 2017 and other current transfers (e.g. grants in the context of foreign economic aid). Related to 2017 the highest level of expenditures on executive and legislative organs were reported by Croatia ( $4.1 \%$ of GDP), while the lowest were reported by the United Kingdom ( $0.9 \%$ of GDP) and Ireland ( $1 \%$ of GDP).

\subsection{Defence}

At the level of EU countries, government expenditure on defence decreased over the 2008-2017 period from $1.5 \%$ in 2008 to $1.3 \%$ of GDP in 2017 . The highest levels have been recorded in Greece during the whole analysed period (3\% of GDP in 2008 and $2.5 \%$ of GDP în 2017), United Kingdom $2.4 \%$ of GDP in 2008 and $1.9 \%$ of GDP in 2017, France (1.9\% of GDP both 2009 and 2010) and $1.8 \%$ of GDP în 2017, Poland $1.9 \%$ of GDP in 2008 and $1.7 \%$ of GDP in 2017 while the lowest level of expenditures on defence were reported in Ireland $0.4 \%$ of GDP between 2008 and 2014 and $0.3 \%$ of GDP between 2015-2017, Luxembourg in the range of $0.3 \%-0.5 \%$ of GDP, Malta $0.5 \%-0.9 \%$ of GDP, Austria $0.6 \%-0.9 \%$ of GDP.

Two high-income countries (Germany, France), a lower income country, Romania, and the data for EU 28 were chosen for a comparison exercise regarding government expenditures on defence. Figure 4 presents the evolution of government expenditures on defence in Germany, France and Romania, as well as for EU 28 countries. There is a significant increase in Romania in 2016 and 2017, while in Germany and France expenditures are almost constant. Also, we can see that the expenditures on defence in the highincome countries (Germany, France) are much larger compared with lower income countries like Romania.

As seen in Figure 4, the level of the EU-28, almost the whole part of defence expenditure is devoted to 'military defence' (1.4\% of GDP in 2009 and $1.2 \%$ of GDP in 2017) followed by 'civil defence' and 'foreign military aid'. Countries like Germany, Spain, France, Luxembourg, Portugal, Slovenia, Finland and Sweden spent about $0.1 \%$ of GDP for 'foreign military aid'. Regarding to the field of research and development (R\&D) on defence the government expenditure was negligible in most countries except for United Kingdom (0.1\% of GDP). According to Eurostat at the level of the EU-28, $46 \%$ of total expenditure on defence in 2017 was devoted to employee's wages, as well as employers actual or imputed social contributions $31 \%$ was devoted to intermediate consumption and $20 \%$ to capital investments (such as new equipment).

\subsection{Public order and safety}

Expenditure on 'public order and safety' is divided into the following categories: 'police services', 'fire protection services', 'law courts', 'prisons', 'R\&D related to public order and safety' as well as expenditure not elsewhere classified. At the level of the EU28 , the expenditure on 'public order and safety' decreased in 2017 (1.7\% of GDP) compared to 2008 


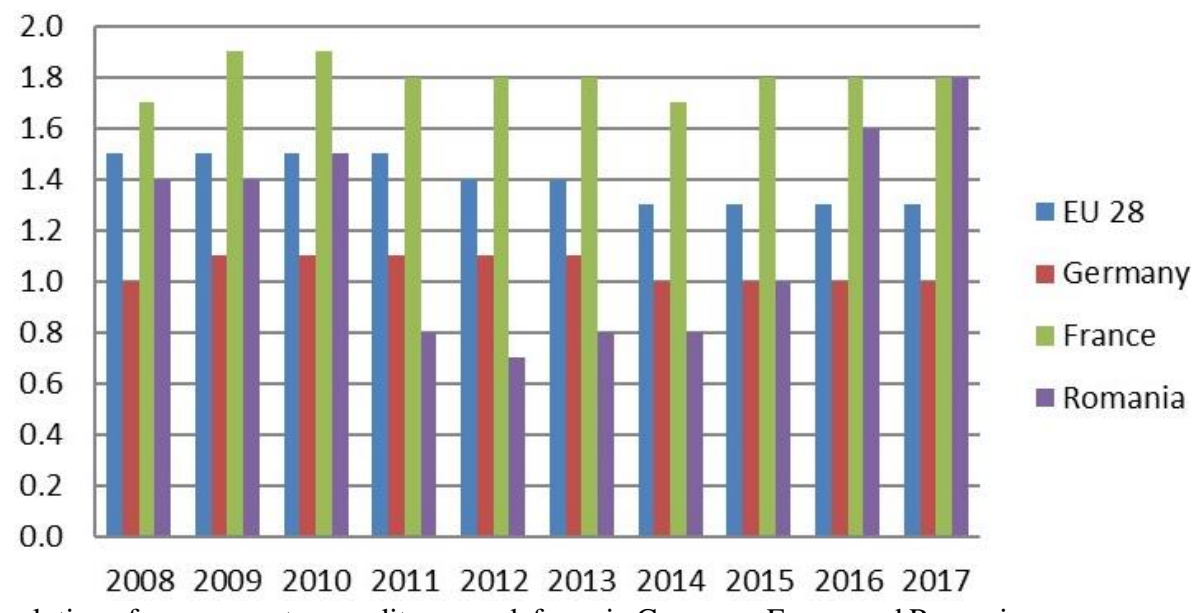

Figure 4. The evolution of government expenditures on defence in Germany, France and Romania, source: processed by authors based on data from Eurostat (gov_10a_exp)

(1.8\% of GDP). The highest level of expenditure on 'public order and safety' in 2017 was identified in Bulgaria (2.5\% of GDP), Hungary (2.4\% of GDP), Latvia (2.3\% of GDP), Croatia (2.2\% of GDP) and lower in Denmark $(0.9 \%$ of GDP) and Ireland (1\% of GDP).

As it can be seen in Figure 5 in 2017 at the level of the EU 28 the major part of expenditures on public order and safety were devoted to police services (53\% of total expenditure on public order and safety) followed by law courts $17 \%$, fire protection services (including in fact all civil protection operations) and prisons both with $12 \%$.

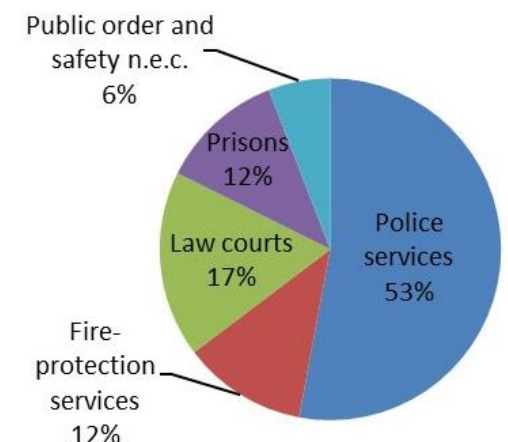

Figure 5. The structure of expenditures on public order and safety in 2017 at the UE level, source: processed by authors based on data from Eurostat (gov_10a_exp)

Countries like Greece and Hungary (both $1.4 \%$ of GDP) spent the highest amount on police services (including border and coast guards) followed by Croatia, Cyprus and Latvia (all 1.3\% of GDP). The most part of expenditure on public order and safety represent salaries and social contributions for police, judges, firemen and prison guards.

The expenditure on fire protection services at the level of EU 28 remained constant ( $0.2 \%$ of GDP) for the examined period. Among the countries with the highest level of expenditure, $0.3 \%$ of GDP in 2017 are mentioned Romania, Greece, Bulgaria, France, Czech and Finland. At the opposite side, Denmark,
Ireland, Luxembourg, Malta, Portugal and United Kingdom registered expenditures on fire protection services less than $0.1 \%$ of GDP in 2017.

Expenditure on 'law courts', including courts operation and the justice system had the highest level in Bulgaria, ranging between $0.5 \%$ of GDP in 2010 and $0.7 \%$ of GDP in 2015 followed by Romania $0.5 \%$ of GDP in 2017.

Expenditure on prisons ranged between $0.1 \%$ and $0.2 \%$ of GDP in all countries except the Netherlands ( $0.4 \%$ of GDP most of the time and $0.3 \%$ of GDP in 2017).

\subsection{Economic affairs}

According to COFOG, government expenditures on economic affairs at the level of the European Union are divided in: general economic, commercial and labour affairs; agriculture, forestry, fishing and hunting; fuel and energy; mining, manufacturing and construction; transport; communication; other industries; R\&D economic affairs; economic affairs n.e.c. In 2017 in the EU-28, total expenditure of general government on 'economic affairs' decreased at $4.0 \%$ of GDP, in comparison to 2008 (4.6\% of GDP). This descending trend is encountered also at the level of the Member States. It can be observed considerable variations of expenditure on economic affairs, for example Ireland encounter the highest value of expenditure on economic affair (25\% of GDP) in 2010 and the lowest (2.3\% of GDP) in 2017. Important variation of expenditure was also encountered in Greece (16.4\% of GDP) in 2013 compared with (3.6\% of GDP) in 2017. These may be influenced by operations of an extraordinary nature, such as capital injections recorded as capital transfers and other categories of capital expenditures. The lowest values on economic affairs were identified in Denmark and ranged between $2.8 \%$ and $3.6 \%$ of GDP.

In what regards the divisions of economic affairs it was noticed that at the level of EU28 the expenditure on 'transport' amounted $49 \%$ of economic affairs ex- 


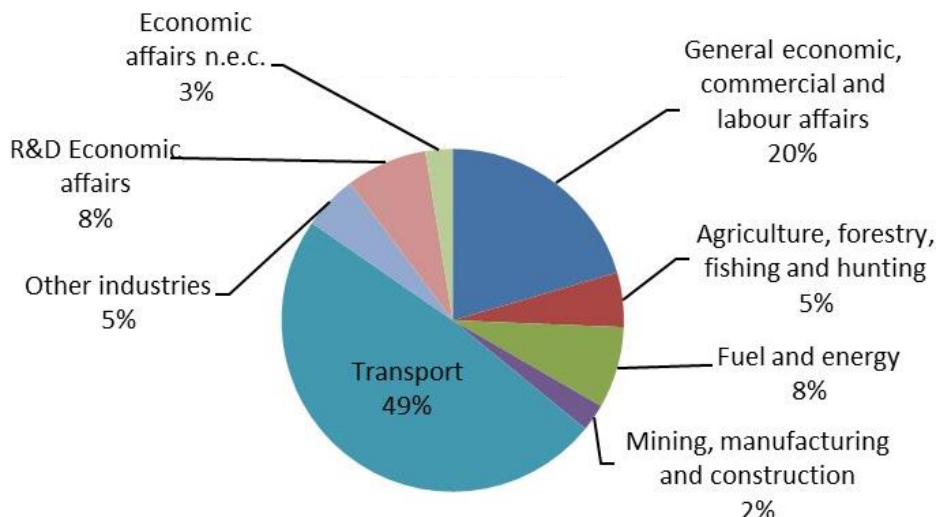

Figure 6. Structure of expenditures on economic affairs in 2017 at the EU level, source: processed by authors based on data from Eurostat (gov_10a_exp)

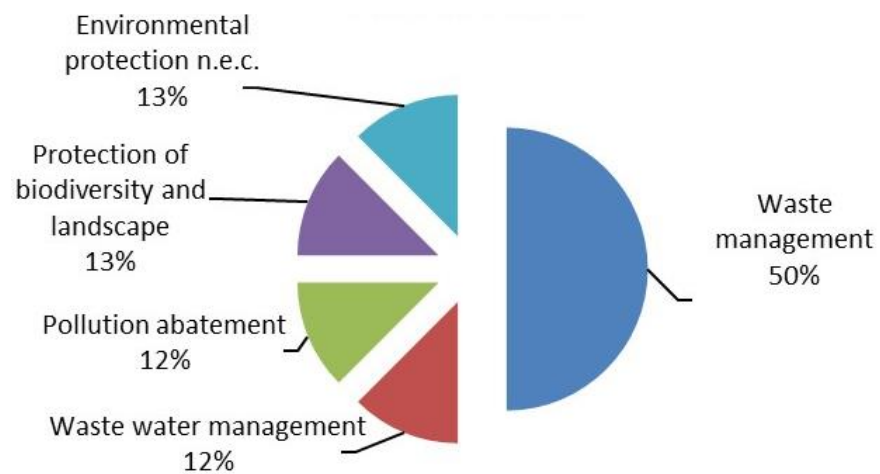

Figure 7. Structure of government expenditures on environmental protection in 2017, source: processed by authors based on data from Eurostat (gov_10a_exp)

penditure (figure 6) in 2017, followed by expenditure on 'general economic, commercial and labour affairs' with $20 \%$ of economic affair expenditure, research and development related to economic affairs (R\&D economic affairs) and 'fuel and energy' both with $8 \%$, 'agriculture, forestry and fishing' and 'other industries' both with 5\%, 'mining, manufacturing and construction' and expenditure not elsewhere classified (n.e.c) summing 5\%, while communication around $0 \%$. The highest expenditure on general economic, commercial and labour affairs was encountered in Ireland (19.1\% of GDP) in 2010, Greece (11.4\% of GDP) in 2013, and Belgium (3.2\% of GDP) in 2017.

Related to expenditure on transport, the highest were recorded in Slovakia (5.2\% of GDP) in 2015 followed by Romania (4.9\% of GDP) in 2012. In 2017, the highest expenditures to GDP ratios for 'transport' were recorded in Luxembourg and Hungary (both $3.8 \%$ of GDP), Czech Republic and Slovakia (both $3.2 \%$ of GDP). An important fact related to the expenditure on transport is that they depend on the value of subsidies given to public or private transportation companies, expenditure of transport companies and transport infrastructure.

\subsection{Environmental protection}

The expenditure for environmental protection, presented in Figure 7, are divided as follows: waste management, waste water management (including sewage systems), pollution abatement, protection of biodiversity and landscape, R\&D environmental protection, environmental protection n.e.c..

In 2017 in the EU-28, expenditure on 'environmental protection' recorded $0.8 \%$ of GDP. As it can be seen in Figure 7 half of expenditures are devoted to 'waste management' $(0.4 \%$ of GDP), followed by waste water management, 'pollution abatement', 'protection of biodiversity and landscape' and expenditure not elsewhere classified relating to environmental protection (both $0.1 \%$ of GDP). At country level, Netherlands and Greece amounted the highest value of expenditure on 'environmental protection' (1.7\% of GDP) in 2009 and 2013, respectively.

In 2017 the Netherlands reported $1.4 \%$ of GDP to 'environmental protection' (of which, $0.5 \%$ of GDP on 'waste management', $0.4 \%$ of GDP on 'waste water management', $0.3 \%$ on 'pollution abatement', $0.1 \%$ on Protection of biodiversity and landscape), while Finland reported only $0.2 \%$ of GDP, followed by Cyprus and Sweden both with $0.3 \%$ of GDP. For 'Waste management', Member States allocated between $0 \%$ of GDP (Ireland) and $0.6 \%$ of GDP (Greece and Bulgaria) in 2017. Regarding waste water management the highest ratios to GDP were recorded by Luxembourg ( $0.5 \%$ of GDP), while the highest value for 'pollution abatement' was reported by Greece ( $0.7 \%$ of GDP). For the 'protection of bio- 
diversity and landscape', the countries allocated $0.2 \%$ of their GDP or less.

\subsection{Housing and community amenities}

The government expenditure on 'housing and community amenities' by COFOG contains: 'housing development', 'community development', 'water supply' (provision of water to households and businesses), 'street lighting', 'R\&D housing and community amenities' and 'housing and community amenities not elsewhere classified.

Over the 2008-2017 periods at the EU 28 level the expenditure on 'housing and community amenities' followed a descending trend from $0.9 \%$ of GDP to $0.6 \%$ of GDP. It can be seen in figure 8 that in 2017 the expenditures on 'housing and community amenities' were shared into 'housing development' and 'community development' (both $0.2 \%$ of GDP, $33 \%$ of expenditure on housing and community amenities, respectively) and 'water supply', 'street lighting' (both $0.1 \%$ of GDP).

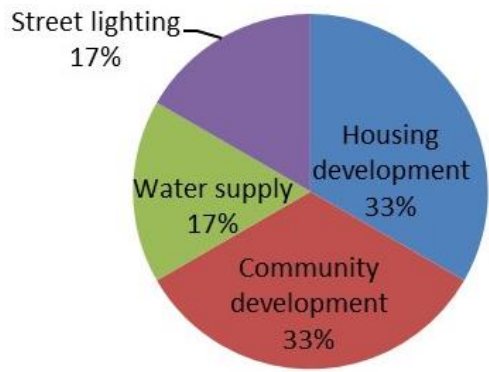

Figure 8. Structure of the government expenditure on Housing and community amenities, 2017, source: processed by authors based on data from Eurostat (gov_10a_exp)

It was observed that, over the analyzed time period, the following countries: Bulgaria, Cyprus, France and Romania reported the highest expenditure on housing and community amenities, ranged between $0.9 \%$ and $1.9 \%$ of their GDP. At the opposite side are situated Greece and Denmark (both $0.2 \%$ of GDP in 2017), Belgium and Netherlands (both $0.3 \%$ of GDP in 2017).

\subsection{Health}

Health expenditures are located on the second place in what regards the general government expenditure after social protection. In 2017 in the EU-28, expenditure on 'health' amounted 7\% of GDP (1080 billion Euro), decreasing compared with 2009(7.3\% of GDP).

Figure 9 shows the division of the health expenditure at the level of EU in 2017, in the following sectors: hospital services ( $46 \%$ of health expenditure), outpatient services (32\% of health expenditure), medical products, appliances and equipment (15\% of health expenditure), public health services, R\&D health and health n.e.c. (all summing 7\% of total expenditure on health).
Over the 2008-2017 period Denmark (8.9\% of GDP in 2009), France (8.2\% of GDP in 2014), Belgium (8.1\% of GDP in 2014) recorded the highest expenditure on health, while Cyprus (2.6\% of GDP), Latvia (3.5\% of GDP) and Romania (3.6\% of GDP in 2008 and $4.3 \%$ of GDP in 2017) reported the lowest.

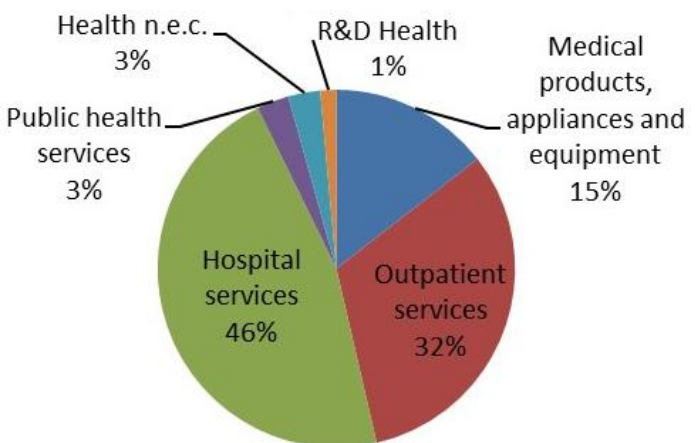

Figure 9. Structure of government expenditures on health in 2017 at the EU level, source: processed by authors based on data from Eurostat (gov_10a_exp)

At the level of the EU-28, the expenditure on 'health' increased in 2009 (7.3\% of GDP) was followed by a decrease in 2011 (7.1\% of GDP) and another increase in 2013 (7.2\% of GDP), amounting to $15.3 \%$ in 2017.

\subsection{Recreation, culture and religion}

At the EU level, expenditure on 'recreation, culture and religion' amounted to $1.1 \%$ of GDP except for 2009 and 2010 when had recorded $1.2 \%$ of GDP. As it can be seen in Figure 10, in 2017 at the level of the EU 28 the main part of expenditure on 'recreation, culture and religion' was devoted to 'cultural services' (40\% of total expenditure) followed by 'recreational and sporting services '(30\% of total expenditure, 'broadcasting and publishing services' (20\% of total expenditure), 'religious and other community services'( $10 \%$ of total expenditure).

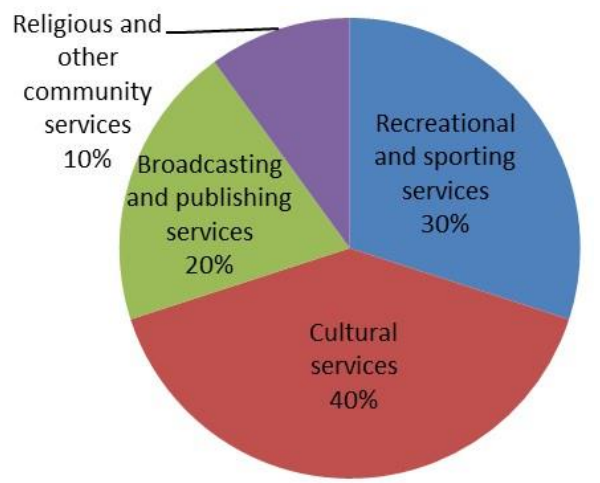

Figure 10. Structure of government expenditures on recreation, culture and religion in 2017, source: processed by authors based on data from Eurostat (gov_10a_exp)

In 2017, Ireland registered the lowest ratio ( $0.5 \%$ of GDP) devoted to 'recreation, culture and religion', followed by United Kingdom ( $0.6 \%$ of GDP) and 
Greece $(0.7 \%$ of GDP) while Hungary $(3.5 \%$ of GDP), Estonia and Croatia (both $2.1 \%$ of GDP) registered the largest ratio.

\subsection{Education}

In the COFOG classification expenditure on 'education' is divided as follows: pre-primary and primary education, secondary education, post-secondary non-tertiary education, tertiary education, education not definable by level, subsidiary services to education (e.g. expenditure on providing school buses), R\&D education, and education not elsewhere classified.

At the level of EU-28 expenditure on education increased in 2009 (5.2\% of GDP), and decreased over the 2011-2017 period from 5.2\% of GDP in 2010, to $4.6 \%$ of GDP in 2017. Based on the data in Figure 11 , the main part of total expenditure on education is devoted to secondary education (38\% of total expenditure on education) followed by pre-primary and primary education $(32 \%$ of total expenditure on education), tertiary education ( $15 \%$ of total expenditure on education) and subsidiary services to education ( $7 \%$ of total expenditure on education).

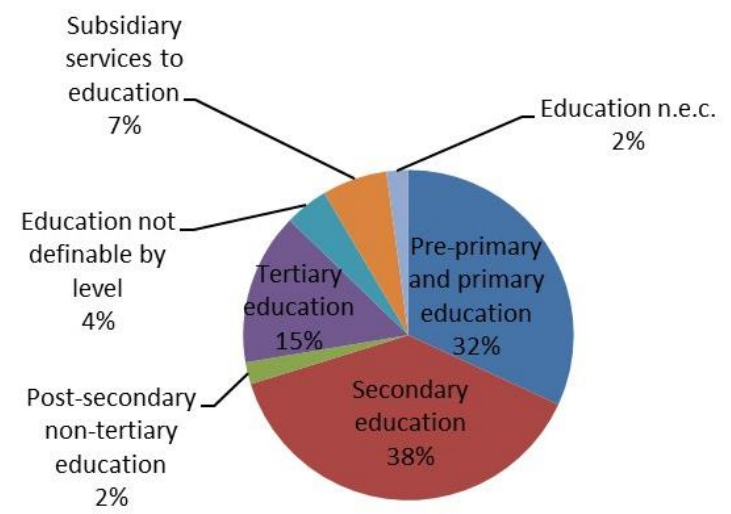

Figure 11. Structure of expenditures on education in 2017 at the EU level, source: processed by authors based on data from Eurostat (gov_10a_exp)

As percentage of GDP in 2017, the highest amounts were reported by Sweden (6.8\% of GDP), Denmark (6.5\% of GDP), followed by Belgium (6.3\% of GDP), Estonia and Latvia (both with $5.8 \%$ of GDP) while the lowest ratios of total expenditure were observed for Romania (2.8\% of GDP), Ireland (3.3\% of GDP) and Bulgaria (3.6\% of GDP).

\subsection{Social protection}

Social protection has had the largest share in government expenditure throughout the 2008-2017 periods in all EU Member States. At the level of EU 28 expenditure on social protection recorded a significant increase in 2009 (19.4\% of GDP) compared to 2008 $(17.4 \%)$, followed by small fluctuations $( \pm 0.1-0.2 \%$ of GDP). In 2017 in EU28, expenditure on social protection amounted to $18.8 \%$ of GDP $(41.1 \%$ of total government expenditure) and involved social benefits approximately $89 \%$, wages and salaries of staff administrating social protection 5\%, intermediate consumption $3 \%$ and $2 \%$ for other current transfers (e.g. to non-profit institutions serving households). The highest values for social protection expenditure, over the 2008-2017 period, were found in Finland (25.6\% of GDP in 2016), Denmark (24.8\% of GDP in 2010), France (24.5\% of GDP in 2016), and the lowest values were recorded in Bulgaria (10.7\% of GDP in 2008), Cyprus (10.2 of GDP in 2008) and Latvia (9.1 of GDP in 2008). In 2017 can be noticed a decrease of expenditure on social protection compared to 2016, thus the lowest level of expenditure could be seen in Ireland (9.5\% of GDP), Lithuania (11.2\% of GDP), Malta (11.3\% of GDP), Romania (11.7\% of GDP) and the highest was reported by Finland (24.9\% of GDP), France (24.3\% of GDP), Denmark (22.4\% of GDP), Italy (20.9\% of GDP).

In 2017 at the level of EU 28 (Figure 12) the most significant expenditure on social protection is represented by 'old age' (54\% of total expenditure on social protection and $10.1 \%$ of GDP) followed by 'Sickness and disability' (14\% of total expenditure and $2.7 \%$ of GDP), 'family and children'(9\% of total expenditure on social protection and $1.7 \%$ of GDP), 'survivors' (7\% of total expenditure or $1.3 \%$ of GDP), 'unemployment' (6\% of total expenditure and $1.2 \%$ of GDP), 'social exclusion'(5\% of total expenditure and $0.9 \%$ of GDP), 'housing'(3\% of total expenditure and $0.5 \%$ of GDP) and 'social protection n.e.c. $(2 \%$ of total expenditure on social protection and $0.3 \%$ of GDP).

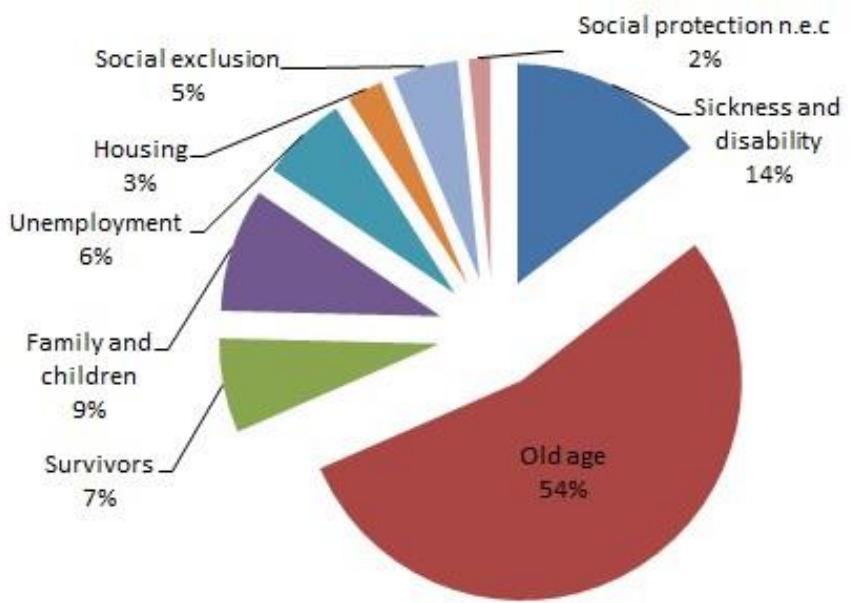

Figure 12. Structure of government expenditures on social protection in 2017 at the EU level, source: processed by authors based on data from Eurostat (gov_10a_exp)

The social protection expenditure on 'old age' relates mainly to pension payments and the highest expenditure was reported in Greece and Finland (13.8\% of GDP), Italy and France (13.4\% of GDP), and the lowest expenditure was in Ireland $(3.4 \%$ of GDP), Lithuania (5.7\% of GDP) and Cyprus ( $6 \%$ of GDP). Expenditure on 'sickness and disability' relates mainly to social payment connected with the operation of social insurance schemes and the 
highest values was recorded in Denmark (4.4\% of GDP), Sweden and Netherlands (4.1\% of GDP), while Bulgaria $(0.2 \%$ of GDP), Cyprus $(0.5 \%$ of GDP), Malta and Romania (1\% of GDP) reported the lowest values. The expenditure on 'survivors', also relates to social benefits and the highest amount was recorded in Italy (2.6\% of GDP), Spain (2.2 of GDP), Greece ( $2.1 \%$ of GDP), Germany ( $1.8 \%$ of GDP), while at the opposite side were located Romania and the United Kingdom ( $0.1 \%$ of GDP), Denmark and Luxemburg ( $0 \%$ of GDP). The expenditure on 'Housing' recorded $0.5 \%$ of GDP at the level of EU28 in 2017 and mainly relates to social protection payments to households to aid with the operation of social housing as well as the housing cost. The expenditure on 'family and children' accounted the highest values in Denmark (4.4\% GDP), Luxemburg (3.7 \% of GDP), Finland (3.1\% of GDP) and the lowest in Greece (0.6\% of GDP), Malta ( $0.9 \%$ of GDP) and Czech Republic (1\% of GDP). During the economic and financial crisis, the rate of unemployment in the EU 28 increased substantially and as an obvious result, the social protection expenditure on 'unemployment' increased from $1.3 \%$ of GDP in 2008, to $1.8 \%$ of GDP in 2009, followed by a descending trend up to $1.2 \%$ of GDP in 2017.

\section{Conclusion}

During the analyzed period government expenditure evolved differently across the EU countries. If at the end of the $19^{\text {th }}$ century in the European countries' government expenditures were less than $10 \%$ of GDP, during the analyzed period (2008-2017), the expenditures exceed $50 \%$ of GDP in many European countries. An increase in expenditures can be noticed at the beginning of the economic crisis in all EU countries, so in 2009 all EU Member States recorded increases in government expenditure, except for Malta. In 2010 and 2011 there were increases in government expenditure in most EU Member States followed by a slowdown in expenditures growth. All countries have adopted policies in order to reduce government expenditures towards the end of the period, aiming to increase their efficiency.

In high-income countries compared with low-income countries, government expenditures are much larger (as \% of GDP). More than half of government expenditures were devoted to the social protection, followed by health, general public services, education, economic affairs, public order and safety, while defence, recreation, culture and religion, environmental protection and housing and community amenities together, represented $5.5 \%$ of EU GDP in 2017. Government expenditure on social protection tends to be higher in rich countries than in poor countries. Taking into account that the world economy is permanently marked by changes at all levels: eco- nomic, financial, political and social, certainly, the structure and amount of government expenditure will undergo changes in the future. Demographic changes, old ages, global heating, unemployment, migration phenomenon, government debt growth in some countries, international terrorism, all will affect the evolution and structure of the government expenditure in the EU and worldwide.

\section{References}

1. ASCHAUER D.A., 1989, Is government spending productive?, in: Journal of Monetary Economics, 23, p. 177- 200.

2. BARRO R.J., 1990, Government spending in a simple model of endogenous growth, in: Journal of Political Economy, 98 S5, p. 103-125.

3. BARRO R.J., 1991, Economic growth in a cross section of countries, in: The Quarterly Journal of Economics, 106, p. 407-443.

4. BECKER G.S., 1962, Investment in human capital: a theoretical analysis, in: Journal of Political Economy, Supplement, part 2, 70 (5), p. 9-49.

5. CASTRO V., MARTINS R., 2018, Politically driven cycles in fiscal policy: In depth analysis of the functional components of government expenditures, in: European Journal of Political Economy, 55, p. 44-64.

6. EUROSTAT, 2019, Database, https://ec.europa.eu/ eurostat/data/database

7. GAMLATH S., LAHIRI R., 2018, Public and private education expenditures, variable elasticity of substitution and economic growth,in: Economic Modelling, 70, p. 1-14.

8. MARGINEAN I., 2014, Public expenditure with education and healthcare in EU countries, in: Procedia Economics and Finance, 8, p. 429-435.

9. IFA A., GUETAT I., 2018, Does public expenditure on education promote Tunisian and Moroccan GDP per capita? ARDL approach, in: The Journal of Finance and Data Science, 4, p. 234-246.

10. KORMENDI R.C., MEGUIRE P., 1985, Macroeconomic determinants of growth: Cross country evidence, in: Journal of Monetary Economics, 16 (2), p. 141-163.

11. LUCAS R.E., 1988, On the mechanics of economic development, in: Journal of Monetary Economics, 22 (1), p. 3-42.

12. MAKSIMOVIĆ G., JOVIĆ S., JOVANOVIĆ R., ANIĈIĆ O., 2017, Management of healthcare expenditure by soft computing methodology, in: PhysicaA, p. 370-373.

13. MLADENOVIC I., MILOVANCEVIC M., SOKOLOV MLADENOVIC S., MARJANOVIC V., PETKOVIC B., 2016, Analyzing and management of health care expenditure and gross domestic product (GDP) growth rate by adaptive neuro-fuzzy technique, in: Computers in Human Behaviour, 64, p. 524-530.

14. SCHULTZ T.W., 1961, Investment in human capital, in: The American Economic Review, 51 (1), p. 1-17.

15. VERGNE C., 2009, Democracy, elections and allocation of public expenditures in developing countries, in: European Journal of Political Economy, 25, p. 6377. 
